Portland State University

PDXScholar

1992

\title{
Within and beyond boundaries in Henri Bosco's Le mas Théotime
}

Barbara Marguerite Schaff

Portland State University

Follow this and additional works at: https://pdxscholar.library.pdx.edu/open_access_etds

Part of the French and Francophone Literature Commons Let us know how access to this document benefits you.

\section{Recommended Citation}

Schaff, Barbara Marguerite, "Within and beyond boundaries in Henri Bosco's Le mas Théotime" (1992). Dissertations and Theses. Paper 4418.

https://doi.org/10.15760/etd.6296

This Thesis is brought to you for free and open access. It has been accepted for inclusion in Dissertations and Theses by an authorized administrator of PDXScholar. Please contact us if we can make this document more accessible: pdxscholar@pdx.edu. 
AN ABSTRACT OF THE THESIS OF Barbara Marguerite Schaff for the Master of Arts in Foreign Language: French presented May 8, 1992.

Title: WITHIN AND BEYOND BOUNDARIES in Henri Bosco's Le Mas Theotime.

APPROVED BY THE MEMBERS OF THE THESIS COMMITTEE:

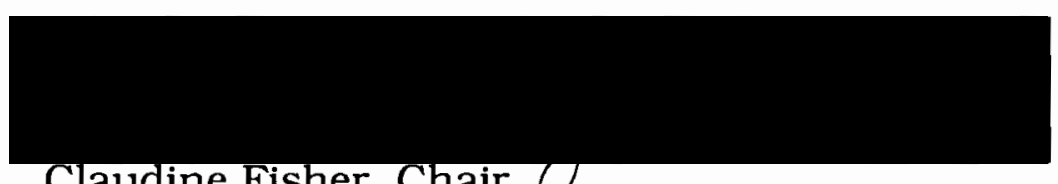

Claudine Fisher, Chair U

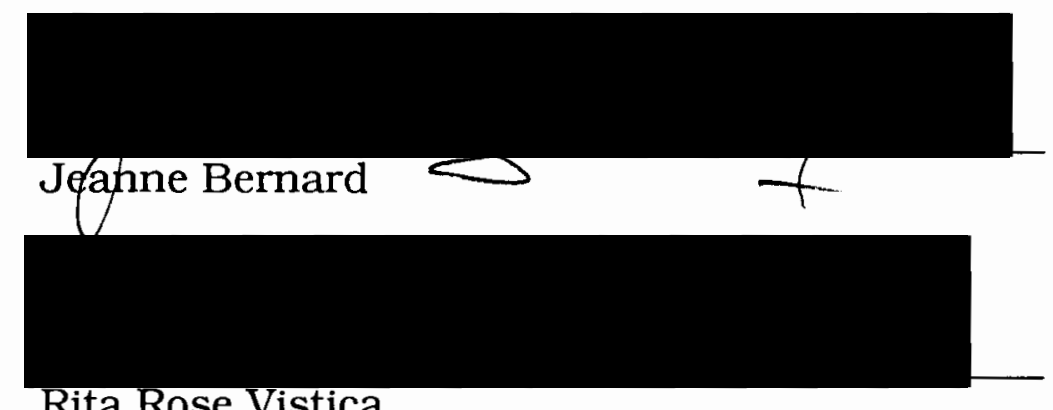

Rita Rose Vistica



Spiritual, mystic and natural boundaries haunt the writings of Henri Bosco. Critics such as Bachelard have studied Bosco's interpretation of the natural elements and noted his sensitive portrayal of the protagonists with a focus on their unconscious desires by the use of this device. In Le Mas Théotime Bosco has unleashed his artistic and 
poetic creativity in addition to his passion for nature. Indeed, of all of Bosco's novels, perhaps this one exemplifies the quintessential harmony of man with nature. As suggested by Jean-Claude Godin: "...il n'y a que dans Le Mas Théotime où elles soient véritablement au coeur du récit...La rêverie de la terre débouche alors sur toutes les images de l'intimite heureuse." (Godin 176) It is also the essence of Provence, its legends and its natural beauty that plays an integral role in this novel. Not only does Bosco explore the natural elements, but he also explores the religious myths that so influence our society.

This thesis will explore, through a symbolic and religious interpretation, the boundaries which prevail throughout. Le Mas Théotime incorporates Bosco's true genius as a writer who brings to his reader the possibility of a personal rendition and view of the story. His is not a straightforward and evident recollection of events, but rather a voyage through and involvement in the lives and minds of the characters.

After a brief introduction in Chapter I, Chapter II will present an examination of the physical confines in this novel including those which exist within the house with an examination of the "grenier", or attic, as the sanctuary for soul. Secondly, the separation between the estates of Théotime, La Jassine and Micolombe will show not only the physical boundaries, but those which are moral and family related as well.

Chapter III will be devoted to the four physical elements, in particular, earth, air and water and their relationship to the protagonists. The identification of Pascal with the earth and Geneviève with air demonstrate, at a different level, the limits which continue to dominate this novel. Moreover, Clodius, who is also of the earth, is put in direct 
opposition to Pascal, for the former is uncultivated and savage while the latter is cultivated and tame. Fire as the fourth element, though not directly referred to in the text, will be discussed briefly regarding the importance of the flame of desire as it relates to Geneviève.

The next chapter will treat family lineage and the frontiers created between the Métidieu, Dérivat and the Clodius de Puyloubier. The demise and decline of the first two families will show the importance of the relationship between Pascal and Geneviève and the creation of a new lineage.

In Chapter V, religion and the "au delà", or the beyond, will explore the limits between different levels of spirituality. Especially the idea of the Fall as it resembles the decline of the paradisical existence between the Métidieu and Dérivat and Geneviève as Eve, the temptress, who entices Pascal. Also, the quest for happiness and paradise will be explored along with the influence of the Rosicrucian order on the ideology and symbolism presented in this novel.

Lastly, Chapter VI is concerned with the use of metaphor to create the images and feelings in Le Mas Theotime. The basis for the analysis of the metaphoric elements will be based on Paul Ricoeur's theory which considers the process of detecting differences through the development of images. Through this device, the reader participates in the creation of the story and an individualization of the text. Chapter VII will offer a conclusion and a suggestion of possible future research. 
WITHIN AND BEYOND BOUNDARIES IN HENRI BOSCO'S LE MAS THEOTIME

\author{
by \\ BARBARA MARGUERITE SCHAFF
}

A thesis submitted in partial fulfillment of the requirements for the degree of

\author{
MASTER OF ARTS \\ IN \\ FOREIGN LANGUAGE: FRENCH
}

Portland State University

1992 
TO THE OFFICE OF GRADUATE STUDIES:

The members of the Committee approve the thesis of Barbara Marguerite Schaff presented May 8, 1992.

Claudine Fisher, Chair

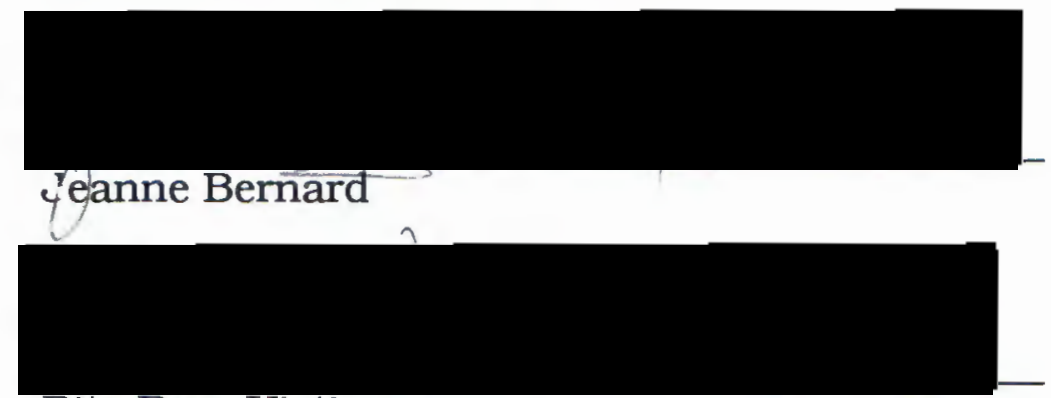

Rita Rose Vistica

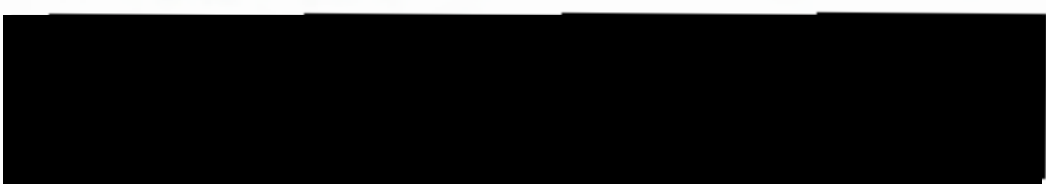

Gregory Goekjian

APPROVED:

Linda B. Parshall, Chair, Department of Foreign Languages and Literatures

C. William Savery, Interim Vice Proyost for Graduate Studies and Research 
DEDICATION

POUR MAMAN 


\section{ACKNOWLEDGMENTS}

Je voudrais offrir mes sincères remerciments à mes professeurs de Portland State University sans lesquels je n'aurais jamais pu réaliser mes rêves. Ces personnes m'ont offert non seulement l'aide académique mais aussi le soutien moral. Merci aux professeurs: Bernard, Fisher et Vistica. Je vous dois tellement et j'espère que je pourrais vous indiquer ma reconnaissance en aidant et en encourageant d'autres étudiants comme vous l'avez fait avec moi. 


\section{TABLE OF CONTENTS}

PAGE

ACKNOWLEDGEMENTS

iii

\section{CHAPTER}

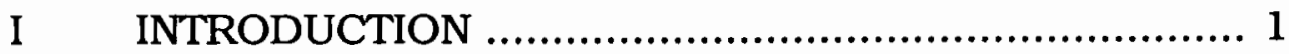

II BOUNDARIES OF THE PROPERTIES ................... 4

III THE ELEMENTS .............................................. 15

IV FAMILY LINEAGE .......................................... 26

V RELIGION AND THE BEYOND ........................... 35

VI THE USE OF METAPHOR ............................... 45

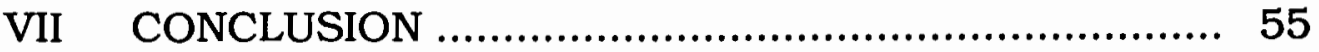

WORKS CONSULTED .......................................... 58 


\section{CHAPTER I}

\section{INTRODUCTION}

Henri Bosco author of such novels as Le Mas Théotime, L'Ane Culotte, L'Antiquaire and Le Jardin d'Hyacinthe is known for his interest in, mysticism, spiritualism and nature. Like Jean Giono, Bosco had a special rapport with nature and his works are known in part for their theme of Man in harmony with nature. His style is by no means conventional and was considered by to bear little resemblance to traditional French literature of the period. Jean Lambert said of Bosco's work that it: "pourrait appartenir à la littérature anglaise du dixneuvième siècle et plus encore au romantisme allemand" (Godin 3). This divergence from what was the norm was in part influenced by the region of Provence, France where he was born and raised and by his voyages to North Africa and Italy. Perhaps these sojourns abroad played the most important role in the development of his writings as he was fascinated by the "au-delà" and humankind's rapport with itself and nature. In these countries with cultures very different from his own he learned to expand his horizons and to explore traditions and myths much different from his own.

His works delve not only into Human Kind's relationship with nature, but also with religious themes and the eternal questions they pose. In addition to mysticism, he was fascinated with the idea of 
paradise and our destruction of it. Therefore, the theme of a solitary hero in quest of this paradise is often found in his works; Pascal in $\underline{\text { Le }}$ Mas Théotime, and Cyprien in L'Ane Culotte are both examples of men who tame nature and learn to live with it in harmony, thus arriving at a type of "terrestrial" paradise and pleasure that Bosco may have found as a child in the countryside of Provence or as an adult in the Atlas mountains of Morocco, for his was a personal quest for happiness and contentment in the bosom of nature and in spiritual fulfillment:

Bosco est en effet hanté par le thème du paradis, par l'obsession d'un état originel de paix et d'harmonie à retrouver. Désir exprimé, parfois, en des symboles transparents; mais non moins visible et présent lorsque l'écrivain évoque d'étranges atmosphères, lorsqu'il peint l'homme cherchant à travers des états incertains de rêve ou d'exaltation presque mystique, un contact, une présence, un dieu. (Godin 6)

Indeed, in Le Mas Théotime Pascal and Geneviève are in a search for their own forms of paradise and confront many obstacles, physical and spiritual, in their attempt at achieving inner peace. The use of the dream and of mystical, as well as spiritual, experiences is in abundance in this work and play a major role in the effective use of the imagination by the reader. In reference to Roland Barthes who differentiates between "plaisir," pleasure, or "jouissance," extreme joy, in reading a text, Bosco definitely invites the reader to partake in "jouissance." The interpretation of the images and the feeling evoked Le Mas Theotime, as well as in his other works, are a particular quality this author embodies in his writings. As Bosco said, mystery mediates in that which is unknowable thus requiring the "reader" to arrive at a personal meaning: 
Le mystère c'est de l'inconnu qui jamais ne sera connu et dont on ne sait qu'une chose - cette impossibilité à être connu. Mais il a cependant une façon à lui de communiquer sa présence, ne serait-ce que par l'existence en nous d'une pensée qui médite sur l'inconnaissable. (Godin 3)

In the pages that follow, Henri Bosco's Le Mas Théotime will be explored with emphasis placed on the bounderies that are found throughout the novel and which are placed in the realms of the physical, metaphysical, religious and metaphorical. 


\section{CHAPTER II}

\section{BOUNDARIES OF THE PROPERTIES}

In the following chapter an examination of the boundaries between the properties in Le Mas Théotime will present those which exist in the house examining in particular the "grenier" or attic as a place of profound meditation and reflection. This is Pascal's sanctuary which protects him from Geneviève's penetrating and probing thoughts. Here he is at one with himself and in communication with his unconscious reflections. Secondly, the confines of the estates of Théotime, La Jassine and Micolombe demonstrate the lengths to which the protagonists will go in order to maintain order and power. In the case of Théotime and La Jassine, going beyond the established borders is a deliberate encroachment on the neighboring farm's owner. Micolombe's established frontiers indicate a separation from this world and one which is closer to God. Indeed the significance of the limits between the estates in this novel are established at different "levels" and will be examined in further detail in the pages which follow..

The farms in Le Mas Théotime are the first limits that become apparent to the reader. Pascal Dérivat's home, the mas, is described as a type of protective mother that provides a sanctuary from the outside world. This house, is the heart of the story as it remains the strength and enduring force that reigns throughout all the struggles of the protagonists: "-Tu aimes la maison? lui demandai-je. Elle réfléchit un 
moment puis me répondit: $-J$ 'aime tout ce qui me protége, Pascal. Le lait était bon, le pain chaud et nous sentions sur nous la puissance du refuge" (Bosco 1952a 62). In addition, the age of the house represents an accumulation of past dreams and sentiments. In Jungian terms, the ancient house is the site of "primitive images" separating this world from the one "beyond." As Bachelard explains: "Ainsi, l'écrivain nous appelle au centre de la maison comme à un centre de force, dans une zone de protection majeure" (Bachelard 1954 45). Indeed it protects and comforts Pascal in a physical as well as psychological and spiritual sense:

Car le vieux mas devenait grand à mesure que le jour montait. Maintenant on en découvrait toute la force: les murs ëpais, les contreforts, la masse bien assise et, tout autour, l'épaulant depuis le sol dur, les étables, les écuries, les granges, les celliers, les bergeries immenses, groupement grave et presque religieux de bâtisses basses, serrées autour de la demeure humaine où vivait le vieux nom de Théotime. (Bosco 1952a 284)

The "protection majeure" of the mas Théotime encompasses the house and the surrounding land. The old "mas" which for generations protected Pascal's ancestors continues in this tradition. It is not exclusively a type of sanctuary, but also provides livelihood through the production of crops and the nourishment of the livestock. It is a micro society, which has its own set of rules of conduct, and of morals.

The house not only provides the physical protection, but also offers Pascal a place in which he can leave this world and enter the one of dreams. This is the true significance of this edifice and it is in the attic where the heart of the house beats and where Pascal's soul and subconscious dwell: 
Je défends ce lieu de rencontre. J'ai peur que la moindre intrusion y dérange le secret de ces habitudes. Toutefois, si j'en ai toujours interdit l'accès à Geneviève, ce fut autant pour elle que pour moi. Je savais qu'il était prudent d'arrêter, une fois au moins, son désir, inlassable à tout pénéter, à tout saisir et à tout perdre. Pour calme qu'elle me parût, je craignais que ce feu ne revint la surprendre. Je pensais donc que le meilleur moyen de lui conserver les avantages de ce nouvel état, d'où lui venait quelque bonheur, était d'abord de ne pas lui livrer le coeur même de la maison, car il n'est sans doute que mon propre coeur, trop sauvage et mal défendu. (Bosco 1952a 67)

Indeed, the symbolic value of the mas Théotime is what Bachelard calls "la maison onirique" (Bachelard 1954 103). This signifies that the house is a refuge, a retreat, a center (Bachelard 1954 102) and symbolizes a welcoming feminine character. In the case of Pascal the house provides this retreat and the attic in particular, protects his innermost sentiments and feelings: "Une maison sans grenier est une maison où l'on sublime mal; une maison sans cave est une demeure sans archétypes" (Bachelard 1963 104-5). Pascal's hours of solitude spent in the attic are those of profound contemplation:

Au grenier se vivent les heures de longue solitude, des heures si diverses qui vont de la bouderie à la contemplation. C'est au grenier qu'a lieu la bouderie absolue, la bouderie sans témoin. L'enfant caché dans le grenier se repaît de l'angoisse des mères: où est-il, ce boudeur?

Au grenier aussi les interminables lectures, loin de ceux qui prennent les livres parce que déjà on a trop lu. Au grenier, le déguisement avec l'habit de nos grands-pères, avec le châle et les rubans. Guel musée pour les rêveries qu'un grenier encombre! Là les vieilles choses s'attachent, pour la vie, dans l'âme de l'enfant. Une rêverie remet en vie un passé familial, la jeunesse des ancêtres. En quatre vers un poète met en mouvement les ombres du grenier. (Bachelard 1963 108-9)

The idea that the attic stores family relics which have a role in the Jungian archetype has significance in that the "grenier" is where Pascal 
keeps and hides the tapestry embroidered by Madeleine Métidieu. This tapestry, as will be examined in a later section, links Pascal and Geneviève with their heritage and guides them in their quest to finding happiness, or rather, a spiritual feeling of contentment and of oneness with their subconscious and ancestral roots:

Ce sont les Dérivat et les Métidieu les plus tendres de la famille, ceux que je voyais à Sancergues dans mon enfance, et quelques autres plus anciens que je n'ai point connus, mais qui viennent pourtant autour de moi. Nul d'entre eux ne me parle, mais souvent leur présence se manifeste à des signes certains qui se forment en moi, dès que ces Ombres touchent à mon âme. (Bosco 1952a 66)

The "maison onirique" indicates that in this dwelling one is at liberty to enter the world of the subconscious and the world of dreams. Indeed, Pascal always goes up to the "grenier" when he wants to be alone with his thoughts. Climbing up to the attic, past the second floor where Geneviève sleeps, he is able to ascend, to go beyond the life here to one "au delà." He is also very protective of this place not allowing anyone to enter it, especially Geneviève, for fear that she should penetrate his thoughts and his real self.

When Clodius' killer is hiding out, it is of great significance that he should choose this room. In doing so he is penetrating Pascal's inner shell and feelings which makes Pascal even more vulnerable because the intruder is able to see where his subconscious resides. In this fashion, the intruder traverses the limits that oblige Pascal to care for his guest, "l'hôte." Both the rules of "guest" and "host" are at stake here. Regardless of the fact that this man is a killer, Pascal cannot betray his own consciousness and his duties as a host. That is to say the intruder who now shares something in common with him: "Chez vous, je ne crains 
pas grand-chose. Je suis votre hôte. Mais une fois dehors, je ne pourrai plus compter que sur moi, alors je reste" (Bosco 1952a 337). Not only is the attic a sanctuary but the mas Théotime is a shelter for all men in the sense that it is linked to God (Théos). Therefore, the attic is connected with Pascal's inner self and the "mas" is a boundary for all who seek refuge; the intruder from the law, and Geneviève from the outside world, which ironically includes her husband, the intruder. In this manner, once again we see the protective value of the "mas" sheltering, in a physical as well as psychological sense, those who dwell within.

Moral limits are also established between Théotime and La Jassine.

This becomes apparent when Pascal fears that he may have killed Clodius in a fit of anger over finding Geneviève with him. He is not disturbed at the thought of having killed his cousin, because he finds him cruel and without redemption. Moreover, La Jassine is a region excluded of any type of morality and upon returning to the "mas," where morality and justice are present, he becomes concerned over his actions:

Il semblera sans doute singulier que j'aie envisagé alors l'éventualité de ce malheur sans que ma chair se hërissât d'épouvante. Car la seule pensée de me trouver à La Jassine en présence du cadavre de Clodius aurait dû la soulever d'horreur. Mais elle restait insensible, J'attribue cette insensibilité anormale à ce fait, non moins singulier, que je n'évaluais pas moralement ce meurtre...Il tenait, selon moi, son corps et sa mauvaise âme hors des lieux où nos actes engendrent des responsabilités. C'est là que je l'avais atteint, mais seul le hasard l'y avait frappé. Sur cette étendue amorale il ne pouvait exister de mouvement coupable; et ma conscience s'y taisait sans effort. (Bosco 1952a 130-31)

It is apparent that the moral limits established by Théotime stop at its borders and it is only upon his return that Pascal questions his actions. La Jassine's amoral limits cause Pascal to feel no remorse. As was 
already suggested, Théotime is a micro society where its inhabitants are judged by rules established within its confines: "Théotime est une sorte d'univers moral clos ou de microcosme éthique ayant ses régles et ses impératifs sans aucun rapport avec la morale ordinaire" (Rosso 157).

In addition to the house as symbol of a sanctuary, it is important to note its relation to the other surrounding estates. First of all, the "mas" is situated in the low lands and is separated from Pascal's other property. Micolombe, by his cousin's house and property, La Jassine. It is of significance to note here the names given to these lieux. Theotime has its base in "Theos", or God. Micolombe takes as its derivative "colombe" or dove, symbol of "the third person of the Trinity: the Holy Ghost..." (Cirlot 85) and "jas" of La Jassine means pastoral (in Provençal). In religious terms the Trinity symbolizes the Father, the son and the Holy Ghost. Here the three properties have a similar connotation. The mas Théotime can be linked to the Father, who creates; La Jassine, to the Son, who saves souls; and Micolombe to the Holy Ghost, who makes holy. Therefore, the mas Theotime is located in the lowlands and is close to its people. Micolombe sits on top of a hill in the "hautes terres," or high lands, and is holy or above the earthly beings: "On s'exalte à Micolombe et l'on se grandit à Théotime. A Théotime l'âme se contient" (Bosco 1952a 91). La Jassine, the pastorals, sits between the two other properties and signifies the shepherd who "is also the conductor of souls to the Land of the Dead-the psychopomp, and a symbol of supreme power, since the flocks are representative of the cosmic forces" (Cirlot 294). The importance here lies in the limits between, not only the physical properties, but more precisely in those which exist between God, 
the conductor of souls to the Land of the Dead and the Holy Ghost. The limits which indicate a passage from this world to the one beyond and also the psychological limits which one must traverse in order to enter the subconscious and the realm of inner satisfaction.

Pascal crosses these borders in the sense that he is "created" when he inherits Théotime, discovering a contentment that he had not before known, and his ascension to Micolombe is the spiritual enlightenment that glorifies and makes holy. Lastly, with the inheritance of La Jassine, the pastoral lands "save" his soul by uniting two families and two properties: "Clodius n'a pas voulu nuire à la terre. Voilà sa vertu éminente, car il eut sa vertu éminente; et sa terre aujourd'hui est tenue par de bonnes mains. La réconciliation est faite" (Bosco 1952a 291). This reconcilitation does not only include that of Théotime and La Jassine, but also Geneviéve Métidieu's "La Maison Métidieu."

The use of property to establish these spiritual, as well as family limits also reflects the importance of owning land. The earth symbolic of growth, stability and, of course, of maternal love. In addition, the cultivation of the land indicates an element of control as well as nurturing. Thétime is the land that is the most nourished while La Jassine, as well as its owner Clodius, are more untamed and savage. Micolombe is, as was already mentioned, in the "hautes terres" and is an area that is in its natural state. This is where Pascal goes to collect his plants and to where Geneviève retreats in order to experience more peace and freedom. The earth nourishes its inhabitants, humans and animals, through the corps that it produces and the home and sense of security 
that it provides. The earth is sincere and speaks the truth; living in harmony with it allows one to have unencumbered thoughts:

La terre ne me leurrait pas, bien au contraire; car, en réveillant ma raison elle soumettait à sa lumière tranquille tous les aspects de ma conduite si contraire à ses lois. Mais comme, après mon hëritage, je l'avais adoptée et rendue à sa vocation séculaire de nourrice des bêtes et des hommes, elle avait acquis sur mes actes des droits puissants qu'un coeur comme le mien ne pouvait pas oublier. Je savais bien qu'un jour ou l'autre elle les exercerait à sa manière, qui est forte, et qu'il faudrait obéir ou disparaitre. (Bosco 1952a 108)

One must respect the earth and the limits she establishes. These refer not only to the physical ones, but also to the limits of reciprocity, that is to say that what is taken from it must also be returned.

The "carraire" that separates Théotime from La Jasssine becomes a source of frustration to Pascal and the Aliberts when Clodius attempts to "cross" these limits. The ancient path used by the shepherds to herd their flocks is one attempt by Clodius to invade Pascal's territory and remove an element of control from his grasp. Indeed, by Clodius entering the Dérivat land, the mother earth and the "mas" become vulnerable to the stranger. The protection of the home from the intruder is an important theme dating from medieval times and Clodius, and later his assassin, represent this threat. The earth belongs to all but, as in any relationship, there are boundaries and agreements which exist between the members involved. The stranger breaks this pact and the mutual trust which reigns and, in a way, contaminates the land. The equilibrium which exists in this relationship is defined by such limits:

L'homme, fils de la terre, s'abandonne au déroulement des saisons, et il y trouve la paix, 'avec une puissance accordée au rayonnement de la matière.' Pascal Dérivat, le héros de 
ce roman, atteint ainsi à un équilibre étonnant. (Godin 152)

Hence, this balance resembles that which prevails between a man and a woman. The sanctity of a relationship embodies limits that must not be crossed:

La terre, et c'est là l'aspect le plus bienfaisant de sa fascination, est d'abord la grande demeure de l'homme, demeure qui lui est chère parce qu'il y est né; et c'est pourquoi l'écrivain note, dans une page de souvenirs: "Coeur et sol ne font qu'un en moi." Simplement parce que l'homme naît sur cette terre, qu'il y vit. "Cela, c'est être, c'est aimer." Et c'est ressentir, obscurément, que la terre est pour chaque homme, une mère dont il cherche à conserver la confiance bienveillante...Le lien entre l'homme, son amour et la terre est donc un lien essentiel, un lieu qui tient "aux racines mêmes de la vie." (Godin 277)

Indeed the mother earth must be protected from the stranger that threatens her security and, of the three estates (Théotime, Micolombe and La Jassine), it is Théotime which is the most cherished and treasured. This is the fertile and cultivated land that nourishes its inhabitants. The other two properties do not reflect this same nurturing trait nor do their inhabitants evoke the same sentiments for them as Pascal does for the "mas." The frontiers between different men must be respected in the same fashion in which those men are allied to their land; to go beyond is tantamount to a type of rape.

Whereas Pascal has a reverence for limits, Geneviève crosses them without any thought of having committed a "moral injustice." In her mind, because there is no fence that physically separates the properties, she is free to go where she chooses. When straying from the designated path, she enters the neighbors' properties. This is in defiance of the 
"rules", but it is when she crosses into La Jassine that she has committed a moral crime:

Il avait une fois ou deux essayé de lui en montrer les bornes: ici finissait Clodius, là commençait Farfaille, et plus loin Genevet. Elle l'écoutait gravement et l'admirait beaucoup d'avoir enfoncé dans le sol tant de pierres très lourdes; puis elle disait: -Je vois bien, monsieur Alibert; mais enfin il n'y a pas de vraie clôture; et alors qui peut m'empêcher, moi, quand cela me plaît, d'entrer dans le champ du voisin, du moment que je n'y fais pas de mal? (Bosco 1952a 68)

As will become apparent later, Geneviève's different set of moral values does not conform with those demanded by Theotime. For this reason, she will not be able to adapt to Théotime, nor to Pascal. Her lack of reverence for the frontiers is unforgivable according to the established creed of Théotime.

Why is man, the male species, that is, so protective of these limits which he has created? Perhaps because man comes from and will return to the land, a land which has belonged to his family, in some instances, for generations. The Aliberts and Pascal build fences to protect their land when Clodius takes his three sheep across the "carraire" and also maintain the three milestones which are markers that separate Theotime from La Jassine. In all these instances it is the men who create the frontiers. The desire is to protect it, but it also is symbolic of the human desire to build barriers between one another and the land is at their mercy. It is only when Clodius dies that the two properties are allowed to be united. Clodius' request to be buried between La Jassine and Théotime is done to show Pascal that he, Clodius, will continue to watch over the property and that each time Pascal and the Aliberts walk on, or near his grave, they will be reminded of his presence and his continued 
ownership of the land. In this fashion, the limits between life and death are dissolved as Clodius' "spirit" will forever remain in the memories of Pascal and of his workers. The last act by Alibert is to bring down the large stone markers that had stood high as a reminder of these divisions:

Tout d'un coup je compris. Car, arrivé au ras de Clodius, il arrêta son attelage. Là se dressait une des grandes pierres limitrophes qui séparaient les deux propriétés...La borne s'abattit...-Monsieur Pascal, à votre tour. Cela vous revient...Je me souviens qu'il faisait déjà très chaud, et que je traçai mon sillon en marchant droit vers Théotime. (Bosco 1952a 371-72)

Thus the physical confines created by man between the estates are brought down by Clodius' death. The limits imposed upon the Earth do not withstand the passage of time and eventually cease to exist, or rather, become redefined, perhaps to undergo further changes in the future. 


\section{CHAPTER III}

\section{THE ELEMENTS}

In the following chapter, the four elements of earth, air. water and fire and their rapport with the protagonists in the story will be examined. First of all, Pascal and his relation to the earth as opposed to Clodius, who is of the earth as well, but who has not learned to tame it and, in turn, to live with it in harmony. In contrast to the earth is air, which is associated with Geneviève and her need to be free and without confines. The element of water is related to both Pascal and Geneviève in opposing ways. For Pascal, as we will see, water becomes a soothing element and a productive force when combined with the earth. However, Geneviève finds it a source of torment and, at the same time, a mirror of truth. Finally, the absence of fire indicates the suppression of passion on the part of Geneviève for Pascal. Indeed the elements have a direct significance with the characters and these implications will be discussed in further detail.

Of the four elements, earth and air are the most closely related to the protagonists. First of all Pascal, as we saw in the previous section, is "un homme de la terre." From the very beginning of the novel we are told about Pascal: "L'air n'est pas mon élément, mais la terre; et j'aime les plantes parce qu'elles vivent et meurent là où elles sont nées" (Bosco 1952a 37). His attraction and devotion to the "mas" and its properties are like that of a son to his mother and truly the "mother earth" provides 
Pascal with security. The qualities of the earth element are lover of babies, of plants, possessive and practical. It is also feminine and receptive. Indeed, these qualities can be attributed to Pascal who collects his plants and nurtures his land. He likewise exercises control over the earth in his pursuit of these activities. The earth attracts and controls and is in this sense malefic. Therefore, there must exist between earth and Man, as it does with Pascal, an exchange of mutual respect:

Mais à l'attachement nostalgique qui porte l'homme vers la terre, celle-ci répond par une sorte d'amour dévorant. Elle attire l'homme vers elle, comme par l'intermédiaire d'ondes magnétiques. Et c'est, en elle, la puissance dangereuse de la matière qui "aspire" l'humain, l'abaisse. On voit comment, alors, le lien essentiel et instinctif entre l'homme et la terre se trouve transformé, porté au niveau psychologique, voire métaphysique. (Bcsco 1952a 278)

Pascal, in his cultivation of the land, is not "aspirated" but rather has been able to create an equilibrium between himself and the earth. While on the other hand. Clodius, who is also of the earth, does not nurture it and maintains it in a "raw" or "savage" state, he is in a way devoured by it; it is the earth who controls him. La Jassine is not described as maternal and bountiful nor is Clodius at terms with it:

Selon Clodius, la culture constituerait une violation de la vocation de la terre puisqu'elle contre-carrerait la perpétuation de son état de nature. Par son respect exclusif du droit de la terre inculte, par son refus de la loi agricole, il affirme son assujetissement au pouvoir de la matière dont la terre est symbole. Il n'est nullement question dans son cas, contrairement à celui de Pascal, d'instituer entre lui et la terre un échange équilibré, structuré par la complémentarité de manques et d'aspirations réciproques, mais bien plutôt d'une abdication de ses devoirs de cultivateur, d'un reniement de sa vocation d'homme de la terre. (Smith 68)

Therefore, Pascal has found his paradise in controlling this element. He is not devoured by it in the way in which is Clodius. Pascal, peaceful 
tamer, Clodius, savage beast; their names indicate the true sentiments of their characters. The peace which reigns at the "mas" is due to Pascal's taming of the land and, as was already said, to his respect towards it. The love that he and the Aliberts bring to it create a type of micro society, a social structure that rests on harmony between humankind and nature. But, as in most societies, anarchy must be avoided through the use of order and this is achieved with the cultivation of land to meet the needs of the people and animals living there.

It is also for this reason that Pascal and Geneviève can never be happy together for she is of the air and cannot be tamed:

Elle était déjà grande, leste, un peu rousse, hardie et offrait alors quelque image d'une créature du vent, s'il en est. Ces crëatures-là on peuí bien les aimer, je pense, mais on ne les retient pas longtemps à la portée de son amour." (Bosco 1952a 17)

According to Cirlot, the air is active, male and is connected with the idea of creation (Cirlot 6). Geneviève, from which we can derive "Eve" brings with her to the "mas" a sense of life:

La maison devint douce et propre. Elle l'était déjà par les soins de Marthe Alibert et de Françoise; mais la douceur et la propreté qu'y porta Geneviève avaient un charme indéfinissable. Du haut en bas on y sentait la cire fraîche. le savon, le miel et le pain de ménage. Des pièces, depuis très longtemps condamnées, s'ouvraient l'une après l'autre à l'air de la campagne qui en emportait la tristesse; et les meubles se mettaient à luire doucement, surtout les vieilles armoires pleines de linge que personne n'avait jamais ouvertes depuis la mort de l'oncle Théotime. (Bosco 1952a 166)

The country air that blows away sadness and brings new life is indeed the metaphor associated with Geneviève. She brings to Théotime a certain warmness which did not exist before her arrival and is the one 
who crosses the borders between the neighboring farms and ventures onto La Jassine, meeting Clodius. This act of crossing frontiers is unique to her and her trait of "air." Her presence will make it possible for Pascal to actually cross over into La Jassine and to confront Clodius. This step in itself is a premonition of the future inheritance of La Jassine by Pascal. Perhaps if this eventful evening had not taken place, the reunification of Théotime and La Jassine would not have either. Air, the "creative breath of life" (Cirlot 6), breaks down the barriers between frontiers and propagates a new beginning. Hence "Eve" is the mother of creation, the one who is the intermediary between good and evil.

It is also why Pascal gives Micolombe to Geneviève, because it rests in the "hautes terres" and she is in need of the liberty and freedom that it has to offer. Here she rejoices in her element and her soul leaves the confines of her body. She has to have this liberty in order to cross not only physical limits, but those which are spiritual as well. Geneviève is too much of air though, going to extremes in exaltation and in her attraction to the primitive forces of nature:

Aussi "en lui accordant Micolombe" il cède, dit-il, "aux puissances d'exaltation de Geneviève", à ces puissances qu'elle cherchait, en venant à Théotime, à équilibrer par le recueillement. Mais il ne regrette pas son geste. Car Geneviève ne peut se sauver à Théotime, c'est à dire dans une structure humaine stable et paisible. (Godin 290)

The dichotomy between Pascal and Geneviève is made more apparent when one remarks that Pascal collects his plants when he goes to Micolombe whereas Geneviève finds contentment in the freedom which dwells there; he is not able to simply let go. This control over the earth, as was already noted, allows him to live in equilibrium with it. There is 
nothing more controlling than putting plants in a book and labeling them. Pascal, who cultivates the earth, also catalogs it and furthers his control over it by enclosing parts of it in a book.

Geneviève, though she is of the air, is controlled by the earth in that she roams over the land trying to find an inner peace, but in doing so becomes its victim. Her sorceress traits date back to when she was a child, building an altar and communicating with nature:

Ces lieux de rendez-vous s'abritaient sous trois grands ormes. Elle y plaçait soit une pierre carrée soit un petit banc de bois. Sur ces autels puérils, qu'elle ornait de feuilles et de fleurs, on voyait de miniscules cruches de verre et des bols. Parfois elle appuyait son oreille contre le tronc de l'arbre; puis elle parlait. (Bosco 1952a 20)

This demonstration may be interpreted as a type of druid, mystical or religious service, linking her to Madeleine Dérivat. Perhaps it would be appropriate to associate this scene with her later experience with the wild boars and the supernatural powers that she displayed. As described by Godin:

Livrée à elle-même, elle se découvre possẻdée par le génie de la terre, emportée, par un mouvement spontané de son âme, vers le cortège de Pan et de Dionysos: et cela révèle bien la nature de sa passion, de son "désir presque surnaturel de liberté", mais d'une liberté folle qui la posséde. Courir au milieu des collines ce n'est pas, pour Geneviève, signe de joie retrouvée; c'est au contraire un funeste présage. (Godin 287)

When she confronts the boars, symbol of the Devil, of Melancholicus and Earth (de Vires 56), Geneviève protects the mas Théotime from the destructive powers of the earth. It is of significance to note here that what separates Pascal from her is a certain mysticism that links her to the boars. As suggests Godin: "Ce qui sépare Pascal de Geneviève, plus que la menace des sangliers, c'est en effet une certain présence-mais 
magique et maléfique-qui lie, dans une communion terrifiante, Geneviève et les bêtes" (Godin 288). Her malefic powers, like those of the earth need to be kept in check, otherwise she is untamed and wild. This is one of the reasons why she came to Théotime, in order to find peace. And yet this is not possible as her desire to traverse the borders between the properties and the joy that she experiences when she is at Micolombe is indicative of this uneasy quest for happiness. Going from Théotime, ascending to Micolombe, and lastly to the Saint Jean chapel indicates a move upward, like the wind to the heavens and to spiritual contentment. Geneviève will have to leave in order to find true joy. The air, which is at one with the heavens, is connotative of a spiritual being that can not live on earth, therefore not at the "mas" where the earth is nurtured, dominated and confined. She must escape these limits, borders and frontiers which dictate and dominate this land.

Water is the third element of importance as it is a type of mirror that allows to see into one's unconscious. Symbolically, it is associated with woman and passiveness. Of all the elements it is the "most clearly transitional, between fire and air and earth. By analogy, water stands as a mediator between life and death, with a two-way positive flow of creation and destruction" (Cirlot 365).

In regard to Geneviève, it is a source of torment, especially stagnating, obscure water. When she accompanies Pascal to the spring, she is troubled by what she sees in the water; a vision of her inner-self. This refers not only to the unconscious, but also to her supernatural side over which she has no control. Looking into the "mirror" she is frightened by something that she does not understand. In addition, the 
combination of water and night allows for a deeper penetration into the imagination. According to Bachelard:

La nuit, au bord de l'étang, apporte une peur spécifique, une sorte de peur humide qui pénètre le rêveur et le fait frissonner. La nuit seule donnerait une peur moins physique. L'eau seule donnerait des hantises plus claires. L'eau dans la nuit donne une peur pénétrante. (Bachelard 1964 139)

Geneviève, looking into the obscure water of the spring is frightened by, not only the vision that she sees in its depths, but also by the dreams that haunt her at night. Indeed, the sorceress at night is the most frightening and Geneviève, who does not understand these feelings, attempts in vain to suppress them. The night at the spring is too insightful or, rather, too truthful. She tells Pascal that he was right not to touch her, and he notices that she is lost in a trance as she gazes into it.

As she is of the air, of the wind, her mobility does not restrict her in any one place and she is free to wander without confronting the significance of her true self. When air and water mix, their combination creates fog, something heavy and confining. Geneviève cannot be constricted by these feelings of being restrained. This is why she knows that she could never live at Thétime; a cultivated land, as we will see later, created by a mixture of earth and water.

Later, when Geneviève has exercised her powers on the wild boars and has come to better understand herself and her sensitivities, the spring no longer affects her in the same fashion:

Elle ne quittait le mas que pour le repos de la source. Cette source qui, une nuit, l'avait tant inquiétée, maintenant la retenait par la limpidité de ses eaux et l'agrément de ses 
ombrages. Elle y passait presque tous les moments de sa journée oisive. (Bosco 1952a 206)

Because, as we said, water acted as mirror reflecting images that she did not understand, Geneviève had been frightened by what she saw and felt. However, when she comes closer to her true destiny and to better understanding her nature, she is no longer tormented. The binary opposition created when air and water met brought to light her veritable need to leave Théotime and to move on to, what is for her, greater spirituality in Nazareth.

In regard to Pascal who is of the earth, the dichotomy between water and the earth is not as disturbing. According to Bachelard, the earth and water together form a "dough" (une pâte), and when it is kneaded or cultivated, is transformed into "life". In addition he states:

Cette rêverie qui naît du travail des pâtes se met aussi forcément d'accord avec une volonté de puissance spéciale, avec la joie mâle de pénétrer dans la substance, de palper l'intérieur des substances, de connaître l'intérieur des grains, de vaincre la terre intimement, comme l'eau vainc la terre, de retrouver une force élémentaire, de prendre part au combat des éléments, de participer à une force dissolvante sans recours. (Bachelard 1964 146)

Pascal's relationship with the earth, with Théotime, is indeed of one who tills the earth, who conquers it and reaps the fruits of its growth:

Pour les êtres qui m'entouraient, ils m'apportaient des satisfactions et des soucis pareils à ceux qui me venaient de la terre. Les soucis qu'elle donne sont mâles et d'une progressive pénétration. Car elle satisfait à ce besoin inné de lenteur solennelle et d'éternel retour que seuls la croissance du blé ou le verdissement des vignes offrent à l'homme qui est aux prises avec la grandeur et les servitudes agricoles. (Bosco 1952a 44)

It is like a man who lusts for a woman; who caresses and seduces her. His relationship with Geneviève is continuously distant because he 
cannot tame her. The limits between Pascal and her are again manifested as their elements, even in combination with a common third element, create a disparity that cannot be overcome. As Pascal conquers and cultivates the land, he fails to do so with Geneviève. The earth and water are both Tertiary, whereas the air is celestial, even when combined with water, though it is laden down, still floats above earth and water. Whereas Pascal feels calm near the spring, Geneviève's agitation demonstrates, not only the mirror affect of seeing something frightening, but also of something confining. Pascal, on the other hand, only feels its nurturing qualities.

Water is also an element in Pascal's dreams, where there is a small boat that crosses a lake. This is a dream involving the Métidieu and the Dérivat, where the souls of both families dwell in the depths of the lake. The boat crosses from one bank of the lake to the other to where the souls of both families reside in a small chapel. Here, water is the intermediary between the living and the dead; the force that crosses between this world and the one "au-delà":

Dans ce paysage se forme le rêve lui-même; il y assemble ses figures propres, variables, selon l'événement qui provoque l'apparition de ce monde irréel, où elles viennent se placer, pour donner des actes du jour l'image reflétẻe et nous livrer le mot qui déforment du tels miroirs, ou du moins l'allusion du songe. (Bosco 1952a 100-1)

The world beyond, and the relationship with the Saint Jean chapel are significant because this is the saint of underground sources and springs and, as the pastor explains to Pascal, all life comes from "les sources," the springs. This is why holy water was sprinkled on the four cardinal points of the fields, from where come the clouds and the winds. Hence, 
there is, a rapport between the earth, water and the air, as the water sprinkled on the land creates the air and clouds. However, unlike Pascal, Geneviève, though she is "created" in this respect from earth and liquid, is unable to stay within the terrestrial limits.

The fourth element of fire can be related to the flame of desire which burns inside of Geneviève and is symbolic of her passion for Pascal. Though it is never overtly discussed in the text, its absence is indicative of the bounderies existing between the two protagonists. Because of their differences and the frustrations that each of them feels regarding the other the flame is never one which burns out in the open, but rather remains hidden inside of Geneviève In addition, fire cannot burn without oxygen and both of them rise, therefore Geneviève does embody this element though she must try to supress it.

Moreover, fire appears in Pascal's dream when he sees a flame burining in the chapel. Here it represents the flame of hope, the candle that is left burning for the lost voyager in order to guide them home. For him, it does connote the image of hope. In fact he hears a voice, which he believes to be that of Geneviève's and it is her that helps him to find his true path to happiness.

The elements, as we have seen, are an integral part of the characters. It is through nature that Man is created and, by the seasons that he/she regulates his/her daily routines. Bosco has presented the elements in such a way as to demonstrate their inner connections with the imposition of confines that, in turn, manifest themselves in the manner in which humans interact together. As Jung suggested with his theory on primitive humans and the archetype, we are all controlled in 
some fashion by our heritage, and by the primitive instincts that have remained tucked away in our unconscious. In the following chapter, the significance of family lineage, in part influenced by the archetype, will be explored. 


\section{CHAPTER IV}

\section{FAMILY LINEAGE}

Family lineage is a subject dear to Henri Bosco. His family has its origins in the region surrounding Avignon, France and, as he was an only child, he was the sole heir to his family name and to its heritage:

La propre vie de Bosco explique ainsi, on le voit, une double particularité des Balesta, Mêgremut ou Dérivat. Ce sont des familles où l'on aperçoit à peine la relation du fils au père et à la mère...Maís le mystère de la solidarité au "clan", à la "tribu", ne tient pas seulement au haut prestige matriarcal inspiré de Tante Martine, Il tient surtout au sang qui coule dans les veines, hérité des plus lointains ancêtres et toujours mystérieusement agissant et fort. (Godin 310)

Therefore, Le Mas Théotime rests on the interactions between the three families of Métidieu, Dérivat, and Clodius de Puyloubier, with their evolution, and is similar to Bosco's own family experience.

In one case, the Métidieu and the Dérivat formed a tightly knit clan that had power and respect in their town of Sancergues. The love and happiness that reigned between the two families was admired by all who knew them. Together they ruled the area of Sancergues which was a type of Paradise and the only dark side to this utopian existence was the family of Clodius de Puyloubiers.

Pascal Dérivat was the "savage" in the family due to the Clodius negative traits that manifested themselves in him. The friction between 
Geneviève and himself would lead to the decline, and eventual extinction of their clan.

In the following pages, the role of the "clan" and its significance in this novel will be examined. In addition, the idea of the decline of a race, as well as the idea of the Jungian archetype will be treated. Lastly, the beginnings of a new order, with the creation of new lineage by both Pascal and Geneviève will conclude this chapter on family lineage and the limits which it erects.

The idea that over a few hundred years the union of the Métidieu and Dërivat families had come to form an idealistic sort of existence is another manifestation of the limits to which this novel alludes. There was never the penetration of an outsider into this special order that caused any type of conflict until the appearance of the Clodius' savage and violent traits in Pascal Dérivat. Until that time the two families had intermarried and had maintained a genre of "superior" race that was the epitome of kindness, love and goodwill. Upon the marriage of a Métidieu and Dérivat there was always a celebration of a new tie that propagated the lineage:

On célébra entre les deux familles, chez des cousins (nous en avions une trentaine), une de ces noces rituelles qui permettaient périodiquement aux Métidieu et aux Dérivat, réunis par un nouveau lien, de se donner toutes les marques quasiment publiques d'une affection toujours ardente à se manifester. (Bosco 1952a 21)

The purity of the blood that passes between them is a way of symbolizing the exclusive nature of their clan and the purity of its origins. Theirs is a bourgeois class that excludes the possible contamination from any outside source, except for the Clodius de Puyloubier blood and lineage. 
Pascal is Métidieu on his mother's side and Dérivat on his father's. It is also on his father's side that the Clodius' entered the family tree. However, the negative Clodius traits do not manifest themselves until they become visible in Pascal.

It is also Geneviève who breaks tradition and up until then, the sanctity of the clan, when she marries someone from outside the two families and leaves her hometown. The disgrace is augmented when she divorces her husband and brings shame to the two families:

Je compris d'ailleurs qu'on envisageait les suites de ce mariage non sans de vives inquiētudes. Elles furent justifiées. Un an plus tard Geneviève quittait son mari, sous un prétexte qui de loin parut futile. Sans doute ne l'était-il pas, puisque cet homme demanda le divorce et l'obtint. Un divorce chez les Métidieu était un malheur inconnu. Une vaste consternation abattit les deux familles. Mais on ne fit pas un reproche à Geneviève; car chez nous on n'accable pas les absents. On prie pour eux et on attend leur retour. (Bosco 1952a 39)

The shame not only lies in fact that she divorced, but also that she was having extramarital affairs. Indeed, Geneviève, like Pascal, is more savage and violent then the others in their "clan." This leads to the next point regarding the decline of the race.

As mentioned, this demise is due, in part, to the contamination of the two families by the Clodius family. It first becomes apparent when Pascal slaps his cousin Geneviève in the face during one of the family functions. This outward act of violence between a Métidieu and Dérivat shocks the group, and more importantly, is the cause of the decline of the clan:

Quand je vis son visage près du mien, je perdis la tête et je la souffletai deux fois. 
Ce geste qui, aujourd'hui encore, me semble inexplicable, eut sur les destinées de nos familles un effet funeste.

De la date, je pense, le relâchement de ces liens qui avaient fait notre bonheur et notre force; quant à moi, j'y retrouve l'origine de tous mes malheurs.

Qu'un Dérivat eût souffletẻ une Métidieu, cela, de mémoire humaine, ne s'était jamais vu. Pourtant il en restait, dans le sang de ces races amies, assez de mutuel amour pour effacer tout ressentiment. Mais entre les deux clans subsista, dès lors, une crainte que rien, pas même deux noces successives ne parvint jamais plus à dissiper. On s'embrassa moins tendrement et le génie de la race tourna vers son déclin. (Bosco 1952a 28-29)

This act of violence is something that is alien and unacceptable to the clan. What was before a paradise is now soiled and tainted by an inferior race, the Clodius de Puyloubier. No longer will the families feel that unique bond which had set them apart from others.

Why does Pascal exhibit this unacceptable and unusual behavior? Perhaps it can be explained by the Jungian theory of archetypes. Bosco introduces the idea that Pascal and Geneviève are set apart from the others in their family through their acts and thoughts. As children Geneviève would escape from the group to build altars and speak to beings that no one else could see. And Pascal not only had these moments of anger (such as the slapping incident), but also left Sancergues to travel to unknown lands and upon his return he found that the exodus of the two families continued on:

Je n'assistai que d'assez loin à cette lente destruction. Toutes les fois que je retournais à Sancergues je constatais bien qu'un viel oncle ou un jeune cousin était parti pour toujours. Mais mon destin semblait me tenir à l'écart de ces malheurs. Je sentais en moi une force inattaquable, comme si le sang Clodius, si âpre, m'eût valu une situation privilégiée au milieu des miens. (Bosco 1952a 38) 
Even as a child he thought that he had a special destiny which included Geneviève. Both felt undefinable inner forces that caused them to act differently from the other members of their families, but they were unable to say from where these sentiments came or to where they would lead.

According to Jung, in every individual there exists influences whose sources are not known and which inexplicably manifest themselves. These archetypes "...belong to the realm of the activities of the instincts and in that sense they represent inherited forms of psychic behaviour" (Jung xvi). In both Pascal and Geneviève these manifestations of the collected unconscious are apparent in their maverick behavior which leads them to be shunned by the clan.

Pascal's communication with the past is noted through his dreams and as suggested by Jung:

Since archetypes are supposed to produce certain psychic forms, we must discuss how and where one can get hold of material demonstrating these forms. The main source, then is dreams, which have the advantage of being involuntary, spontaneous products of the unconscious psyche and are therefore pure products of nature not falsified by any conscious purpose. (Jung 67)

In his dream, Pascal sees, as has already been already brought up, two banks of a lake whose depths are representative of the collected state of the souls from the two families; one side representing the living and the opposite bank the dead, with a small chapel which watches over the side of the dead. He explains that traditionally when a Métidieu or Dérivat experienced some type of event, be it joyful or sad, they would have this dream in the few weeks that were to follow. The dream continues with a small boat carrying characters, phantoms, who will play some role in the 
latent powers of the dream. The image then becomes blurry and the ghosts return to their "country of origin." After the eventful evening at his cousin Clodius where he finds Geneviève, whom he had explicitly forbade to come to La Jassine (Clodius' estate), he has a dream which begins in the traditional fashion. However, when the small boat floats from the banks representing the dead and arrives to the opposite side, there are no passengers. The image here is symbolic of the river Styx or Acheron which seperates the land of the living from that of the dead. Hence a type of purgatory indicating that Pascal is not sure where he is, that is to say, he is in a state of confusion and indecision. The wind then picks up and he hears the voice of someone he at first identifies as that of Geneviève's. No one appears, but he sees that on the banks of the dead, a flame is burning. This is a sign of life that never before appeared in the "clan's" dream:

Sur la rive opposée, où jamais de mémoire de Métidieu et de Dérivat on n'avait aperçu le moindre signe de vie, on voyait une flamme qui vacillait sous le porche de la chapelle.

Le vent tomba, les roseaux cessèrent de se plaindre, et peu à peu la vision se dissipa dans la nuit.

Seule la lampe persista longtemps à trembler dans le vide, alors que le lac et ses rives avaient déjà disparu au fond de l'abîme. (Bosco 1952a 102)

It is of significance to note that Pascal Dérivat is the only member of the two families to have had such a dream and that there were no apparitions representative of the souls of the Métidieu and Dérivat families, to appear to him. The only sign of a vision was the voice of someone he thought to be Geneviève's.

It is possible to interpret this dream as a premonition of the future. That is to say that Pascal, isolated from his other family members, only 
had contact with Geneviève, Clodius, and the cousin Barthélemm Métidieu. Also, in an indirect manner, there was communication with the great aunt Madeleine Métidieu whose embroldered bed cover and its strange cross, haunted Pascal and Geneviève. The light also foresees the fact that Geneviève will follow Madeleine Dérivat's path and enter a life dedicated to God; possibly related to the sainthood.

The fall of the clan is interpreted by the fact that there were no longer any ancestors in the dream to communicate with Pascal. His new beginnings are also alluded to by the fact that, though he and Geneviève share a special bond, their differences are too great to overcome. With her departure from Théotime and with the death of Clodius, he his left with the Alibert to start a new beginning and a new lineage. It is therefore due to Geneviève's arrival and her undesired contact with Clodius that he will later inherit the La Jassine estate.

The power that had, a few hundred years ago, brought together the Métidieu and the Dérivat and had created their utopic union and existence would again lead Pascal to a new beginning. Geneviève, as well, had escaped the disease that was eradicating their two families by leaving for Nazareth and living with a religious order.

This point leads us to the last section concerning the new beginnings. As was stated above, Pascal was led to the path towards a new existence through his devotion the Théotime estate, his inheritance of La Jassine, the departure of Geneviève and lastly, his new union with the Aliberts and his upcoming marriage with Françoise Alibert. Regarding the influence of the Clodius "blood" Corrado Rosso states: 
Ce même sang est en lui également. Il circule en son être lui transmettant l'antique message qui lui fait accepter avec sérénité d'être le dernier de sa race pourvu qu'il demeure fidèle à l'éthique de la tradition. Donc la liquidité du sang est contenue par les solides berges de la fidélité envers le passé. D'où une sorte d'ascèse qui ne peut être pratiquée qu'à Théotime. (Rosso 152)

Thus we can attest to the power of the archetypes and their influence in guiding Pascal, as his devotion to the land is inherited from the Clodius ancestors. The mixture of the two races creates a new harmony: "Le cousin Clodius ne porte en lui qu'une violence négative et destructrice; Pascal, en qui le sang Clodius est mêlé au sang Dérivat, tirera de ces deux sangs réunis une nouvelle harmonie" (Godin 319-20).

Geneviève provides Pascal with the necessary shock in order for him to realize that Françoise Alibert is the woman with whom he should marry and start a new family.

La porte de Théotime était close. Mais j'eus beau chercher Geneviève, je ne la trouvai plus. Elle était partie

D'abord, apparemment, je n'en parus pas très touché; mais aussitôt, avec une clairvoyance bizarre, je compris que j'allais tout de même souffrir. (Bosco 1952a 367-68)

His suffering allows him to see that what awaits him is a healthier and happier existence that he could not have found with Geneviève, nor that she could have found in living with him. It was only necessary to remove the temptation that she provided for him to view Françoise in a new and clear light.

Geneviève's own realization and discovery that her destiny lay in religion and that a life with a religious order would lead her to a new beginning and prevent her from meeting with the same end as her relatives. She, as with Pascal, was always set apart from her family and though she did embody the Métidieu characteristics of love and 
kindness, there was something else which set her apart from them and allowed her to survive the decline of the "superior" race. It was necessary for her to escape by marrying this man who turned out to be violent and a killer. This extreme was needed to counteract the other extreme that the clan imposed on her and its other members. It was too good to last forever and a type of purge was required. This purge came in the form of the extinction of most members of the Métidieu and Dérivat families except for herself, Pascal and Barthélemy.

Though Barthëlemy is not one of the main protagonists, his role is crucial as it provides to Pascal and Geneviève with a link to their ancestry and its good qualities, for he does embody all that was the best of the Métidieu family: "Du reste ce récit coûtait beaucoup à ce Métidieu en qui survivait toute la bonté héréditaire" (Bosco 1952a 43). Moreover, Barthélemy was one of the twelve apostles that had assisted Christ. Here, as was seen, he helps the establishment of Pascal in Théotime and Geneviève with her true calling, never questioning their acts, but rather having faith in their destinies.

The importance of family is quite apparent in Henri Bosco's work. His finesse includes the interpretation of family feuds and how this can create limits which traverse physical boundaries to include those between individuals. Pascal and Geneviève demonstrate new beginnings and hope in the future. Despite the turmoil that plagued their families and themselves they were able to overcome these obstacles and discover their own happiness. 


\section{CHAPTER V}

\section{RELIGION AND THE BEYOND}

Religion held a very important place in Henri Bosco's personal life which is reflected in Le Mas Theotime. The reasons for this perhaps begin with his ancestor Saint John Bosco who was a preacher and writer, as well as organizer of the order of St François de Sales. It is of significance to note that the chapel in the novel is named St Jean and that the order that Madeleine Dérivat and Geneviève join is called the Visitandines and is affiliated with St François de Sales. In addition, Bosco's immediate family was religious and Bosco grew up with a strong Catholic education.

Moreover, Bosco had a certain curiosity for myths and the supernatural. He once said:

C'est à peu près vers l'âge de treize ans que je commençai à prendre le goût étrange de ce qui n'est pas. Je veux dire de ce qui n'est pas pour le commun des hommes: un ange, un secret avertissement, un pays inconnu que l'on reconnaît tout à coup, mais qui ne peut venir à nous que d'un espace vide-aussi vide que le néant... (Godin 5)

Indeed, this fascination with the "au delà," the beyond, was with Bosco from a young age and also from diverse sources; his ancestor, his family, and the myths and legends that live in the region of Provence.

In the following pages the idea of the Fall, as it relates to the paradise created between the Métidieu and the Dérivat will be examined. This will include the idea of Geneviève as Eve, the temptress who 
attempts to seduce Pascal and who also resembles the figure of Mary Magdalen, who sinned in the past but who is then redeemed.

Another significant religious notion included in this novel, is that of the quest towards happiness and paradise. This idea will incorporate the philosophy of the Rosicrucian order and its influence on Bosco, especially in regards to the symbol of the Rose Cross.

Before Pascal's violent act towards Geneviève, the Métidieu and Dérivat had shared a paradisiacal existence. However, as has already been seen, his Clodius "qualities" came to the surface and Geneviève is the person who seems to bring out these sentiments in him. She attempts to seduce Pascal, even when they were children, with her mysterious and sexual manner. Though Pascal, on the surface, is not attracted to her, internally he is deeply troubled by her which resulted in an act of violence. This act is when he slaps her at one of the family reunions. Later in their lives, when she comes to stay with him at Théotime, he worries about her arrival and the problems which she may create. This is why he does not want her to enter the attic of the house, in order to not divulge too much of himself. He attempts to keep a distance between the two of them so that he will not be pulled into her web:

C'est ainsi que la femme joue, par rapport aux héros solitaires, le rôle de tentatrice; dans ce paradis que recherche l'homme, la femme demeure celle qui a écouté le serpent. C'est là un rôle nécessaire, dans la mesure où il permet cette "confrontation" de l'homme avec les forces du mal. "Il s'y définira, déclare Bosco, avec une puissance que nul autre obstacle ne lui eût permis d'atteindre..." (Godin 358) 
Pascal's desire for Geneviève never becomes one that overpowers and controls him. Though she is not "pure" she is not the sole cause of his torment. Indeed, it is upon finding Micolombe that she develops a clearer understanding of who she is and what she must do in order to find happiness. It is this mystic as well as spiritual quality embodying Geneviève that disconcerts Pascal.

As Eve was tempted by the apple, Geneviève is tempted by her inner feelings; feelings which she does not understand and which set her apart from her family. In this manner Pascal, who is also naive of his inner sentiments, lashes out at her because he his afraid of his passion for her. Thus, through this act of violence, never before known to the Métidieu and Dérivat, Pascal and Geneviève are responsible for the demise of their families and the end of the paradise-like existence they had known: "And God banished the couple from paradise and condemned them to work for a living" (Eliade 1978 166). Also like Eve who had two sons, one a shepherd and another who tilled the soil, Geneviève influences two men; Clodius, a shepherd and Pascal, a farmer. The ensuing life at Théotime depicts the life of ordinary humans on earth after Paradise and the struggles of dealing with nature. And just as Geneviève the patron saint of Paris led and reassured the people at the time of Attila, she nutures and guides Pascal to a better life.

The next point regards an interpretation or rather a deciphering of the Rose Cross which appears on the bed cover embroidered by Madeleine Dérivat. The cross is described as having a dove on either side of it, symbolizing the love between the two families and which flies upward carrying the rose cross towards God and spiritual enlightenment. 
The rose and the cross together can be interpreted in many ways such as; the female and the male; the unclean and the purified; the material and the spiritual; sensual love and spiritual love; love and the death which is saved through love. (Cavendish 2424) The significance to Pascal and Geneviève seem apparent. Together they struggle between spiritual and sensual love, between the land, material, and the beyond, spiritual. She is the unclean, the one who has sinned by marrying outside of the family and having an affair.

But beyond the mere interpretation of the rose and the cross, it is possible to apply this symbol to that which belonged to the Rosicrucian order. This group which had its origins in Germany, combined spiritual along with mystical beliefs and supposedly possessed important and arcane wisdom that they transmitted to their spiritual heirs and successors. The legend begins with Christian Rosenkreuz who was the son of noble, but poor, parents who was placed in a monastery at the age of five to learn Greek and Latin. He went on a pilgrimage to the Holy Sepulchre with a monk named Frater P.A.L. The monk died on the way to Jerusalem and Christian continued the journey alone ending up in Damascus. While there he learned from the Wise Men who were mysteriously expecting him. The story continues that Christian remained in the Middle East moving west to North Africa. He eventually returned to Germany where he shared his knowledge with three monks from his old monastery. These were to be the founding members of the Rosicrucian order who together wrote on magic and medicine about which Christian had learned during his voyages. Later on, alchemy 
became more important to the order with Paracelsus becoming interested in their methods and influencing the development of this order in France.

The link of this legend to that the Rose Cross in Le Mas Théotime is tied to the idea of a quest for knowledge and the combination of the spiritual along with the mystical. In the novel, there appears the message on a tablet found in the small St Jean chapel: "Si tu veux retrouver la parole perdue et le séjour de paix oriente-toi" and bit further down on the tablet is written "Il y a un trésor sous cette image" (Bosco 1952 168). This rather cryptic message could be interpreted to mean that the person in question should go to the Orient in order to find the true meaning of life. It is also interesting to note that four letters encircled the Rose Cross. These letters, "H.L.R.M.", resemble the initals given to the monks in the Rosicrucian order. Because they wanted to keep the membership secret, their names were never used. Therefore, precisely for this reason of secrecy it is difficult to decipher the meaning of the four letters. It is possible that the " $\mathrm{M}$ " may relate to Madeleine and it may be a type of title given to her in the order and kept a secret to conform to the Rosicrucian's pact. Indeed Madeleine, along with Geneviève, go to Nazareth to find peace and spiritual fulfillment. In addition the importance of the mystical, as well as spiritual, in this novel cannot be ignored. Geneviève's fascination with the occult, for example in her control of the wild boar, link these phenomena with the Rosicrucians. Since the order gained more importance in France in the eighteenth century and because St Jean Bosco was a learned man the possibility of his becoming interested in such a group is entirely probable. Moreover, Bosco himself spent a great deal of time in North 
Africa where he may have acquired more knowledge on this group, especially since the legend recounts that Christian Rosenkreuz had spent time in this area of the world and, in fact, is where he received most of his education.

Not only can the strict doctrine of the Rosicruicans be related to the novel, but as well the symbolic value of alchemy and of the quest for something greater. The rose and the cross were chosen as the Rosicrucian emblem because of their symbolic value which corresponds to the order's beliefs such as 1) The Cross as the sign of Jesus Christ, therefore the Brotherhoods' dedication to pure mystical wisdom. 2) Its red color representing the mystical and divine blood of Christ, which cleanses all $\sin$. 3) It was worn by the Christian Chivalries in the wars against Turks and Saracens. 4) 'This red Cross is adorned with roses and lilies, because He unto Whom it refers is the 'the Rose of Sharon and the Lily of the Valley'." 5) The color of blood is placed in the center of the Rose to represent the work of the "Sacred and Divine Alchemy in the purification of what is unclean" (Waite 107-8). The symbolic value of the rose and cross also signifies in Christian tradition the transformation of these symbols to represent much more:

Let us look at some other and-within their own measures-very typical conversions. There is that of chivalry by the spirit of romance, converting crude and predatory feudal knighthoods into a great ideal, mystical and holy order, as much and as little on outward land and sea as are the light of "consecration and the poet's dream." It produced a great tradition of impossible books, a world, moreover, of quests and attainments, and high dwellers therein: Arthur and his companies of kings; the Round Table and its "flower of all the world"; Charlemagne, Roland and Oliver, shining among the peers of France; above all Lancelot; and in fine Perceval, and 
Galahad as more than he. This golden tradition gave us Chrisitan womanhood, the type above all womanhood. Now the point is that it took over the rough knighthood and transformed it in its own alembic. (Waite 622-23)

The rose and the cross were chosen, he proposes, because such ideas have a connection with Rosicrucian lore. This is visible in Le Mas Théotime if one considers, for example, Pascal's rescue of Geneviève from La Jassine. As Lancelot went through the forests in search of Guinevere, so Pascal saves Geneviève. In addition, there is the idea of a quest for happiness; a journey that must be travelled and challenges that must be overcome all along the way. Pascal must discover that Geneviève is not meant for him and must, in fact, make a sacrifice. He cannot have her if he wishes to keep Théotime in its present state as Geneviève would ruin the harmony between nature and himself. And likewise she enters a nunnery and goes beyond the mere love of a man who cannot fulfill her needs, to the love of God. Regarding this "rite of initiation" Sandra Beckett confirms:

Pendant son séjour de vingt-quatre années au Maroc, l'écrivain a découvert les ouvrages de René Guénon-dont Aperçu sur l'initiation-qui ont exercé une influence déterminante sur la pensée bosquienne. Bosco s'intéressait vivement au mysticisme islamique et notamment au soufisme, à l'ésotérisme chrëtien des Rose-Croix et des Templiers, aux religions à Mystères du monde gréco-romain, etc. (Beckett 83)

The rites of initiation in this novel are several. For Pascal, he must overcome his passion for Geneviève and come to terms with himself, what he wants, and his future union with Françoise. He realizes that it is with Theotime that he is happiest and that a woman of the earth is what will culminate his contentment: 
De retour à Théotime, je repris mes herborisations, en attendant les vendanges. Je vécus quelque temps à part, à cause de ma peine et du besoin que j'éprouvais de purifier mon coeur d'un désir désormais inutile. Je ne voulais y parvenir que par le seul effort de mon âme, sans recours porté du dehors ni intrusion, même amicale, dans un monde où remuaient encore tant de forces redoutables. (Bosco 1952a 381)

Moreover, it is Geneviève who will assist in making this realization that their union is not possible. In his dream, his vision of the light on the opposite bank and the sound of a voice he believes to be that of Geneviève is an indication of his future destiny. His confrontation of Clodius, when he rescues her, is the point at which he realizes that she is too untamed for him. It is also the opportunity to confront his own "savage side". The Clodius traits are those which caused the demise of his family and also led him to become alienated from his family. Upon this "reunion" the two cousins, though certainly not fond of one another, at least meet and it is at this point that Clodius will decide to leave his estate to Pascal which at last reunites the two families and also makes it possible for Pascal to consider his own future and the propagation of his own lineage.

In Geneviève's case, her initiation is the one to God. Her joy at Micolombe and the discoveries at the St Jean chapel lead towards her destiny of leaving for Nazareth. The scene with the wild boars and her subsequent departure to her cousins Barthélemy alert her to her true calling in life. She has passed from a physical love to one which is spiritual. Her decision is not easy, but as her great-aunt Madeleine before her she has discovered her true calling. The rite of passage is from an ordinary woman who has "desires of the flesh", to one who will 
be closer to God. It is also of interest to note that Geneviève will actually purchase the St Jean chapel and offer it to Pascal. After undergoing renovations it will once more become a site of worship and, more importantly, the spring which was blocked, will again be opened. The "path of God," leading up to the chapel, will welcome the faithful and the spring will flow bringing its life giving powers to those along its path.

-Monsieur Pascal, m'a dit l'abbé, la chapelle est à vous: je vous la livre, comme le donateur, qui l'a acquise et réparée de son argent, m'a prié de le faire...

J'ai signé sans savoir pourquoi. J'ai signé aveuglément. J'ai signé au bas de la feuille d'une écriture, large, ferme:

Pascal Dérivat, propriétaire.

Et puis j'ai lu:

Moi, Geneviève Métidieu, je donne...

Le reste s'est brouillé dans ma tête. Pourtant j'ai essayé de lire encore, d'aller plus loin; mais je devais avoir les larmes dans les yeux, car je n'ai rien pu déchiffrer de ce grimoire. Quand j'ai levé la tête, je me suis retrouvé tout seul, dans la sacristie blanche.

Et alors, je l'avoue, j'ai pleuré sans vergogne, pendant un bon moment. (Bosco 1952a 430-31)

Geneviève finds her "parole perdue" and gives Pascal the most valuable gift of all, the sublimination of their love. Not a simple "earthly" love, but something much more profound. Pascal's tears show the emotion that had grown inside of him and which is now released. He had never shown this type of affection before, nor had he allowed anyone to penetrate into his inner self and know his true feelings. The last act of passage demonstrates how true contentment was discovered. For Geneviève, she learned from Pascal what she needed in life to be happy. Had she remained with her husband or had she continued her life in Sancergues, she would have led a mediocre existence. 
Both Pascal and Geneviève needed each other to show the other the right path to take. The two doves on Madeleine Dérivat's embroidered bed cover are symbolic of the love of the two families and the rose cross in the center indicates the quest for "truth" which must be followed. The demise of the two families regenerated new life which will further the races in a harmony with nature and with the inner consciousness. Indeed the mystery of new life and the journey to something better is the challenge of the Rosicrucian members:

Moreover, the great central sign and symbol of the Rose placed upon a Cross could never, as we have seen, have signified anything but a spiritual and as such a Christian Mystery...

It is this transformation which has come to pass in fact. The Rosicrucian Tree of Life in Kabalism has become the Tree of Life in mystical experience on the ascent of the soul to God. (Waite 625-26)

Hence Madeleine and Geneviève found the "tree of life." Through their devotion to God they both discovered their true calling in life and innercontentment. And because of this joy, Geneviève was able to lead Pascal towards his destiny. In the end, all the protagonists are "reunited." Clodius is reconciled with his cousin Pascal, Geneviève with herself and God, and Pascal with his inner self. The path to God, as described going up to the St Jean chapel, is indeed discovered. 


\section{CHAPTER VI}

\section{THE USE OF METAPHOR}

Henri Bosco demonstrates in his work Le Mas Théotime the use of metaphor in order to achieve a certain metalevel of "feeling" on the part of the reader. That is to say that the use of metaphor implies showing the differences which exist between two objects or ideas, in order to allude to their inherent similarities:

Resemblance ultimately is nothing else than this rapprochement which reveals a generic kinship between heterogeneous ideas. What Aristotle called the epiphora of the metaphor, that is, the transfer of meaning, is nothing else than this move or shift in the logical distance, from the far to the near. (Ricoeur 1990 426)

In this novel, as demonstrated in the previous chapters, Bosco has taken physical confines, elements, family lineage and religion and made a rather cohesive package of the four by describing the rapport between humankind, religion, and nature.

This type of rapprochement of different elements is done through "seeing" that is to say that, as proposed by Ricoeur:

The place and role of productive imagination is there, in the insight, to which Aristotle alluded when he said that to make good metaphors is to contemplate likeness. This insight into likeness is both a thinking and a seeing. It is thinking to the extent that it effects a restructuration of semantic fields; it is transcategorical because it is categorical. (Ricoeur 1990 427)

In the case of Le Mas Thëotime, the likeness between the theme of limits and, for example, the boundaries between the estates creates a 
stronger image of the obstacles which confront the protagonists. The "imagination," as coined by Ricoeur, has to "contemplate" the differences existing between (a) the theme of limits and (b) the boundaries, which in turn can be related to (c) the protagonists. For example, the three large stones marking the division between Théotime and La Jassine, do not only indicate the separation of two properties. They also note the time which has lapsed since the Dérivat and Clodius had been alienated, and symbolize the three families of the Métidieu, Dérivat and Clodius de Puyloubier. As Ricoeur suggested, the imagination must use its insight in order to recognize this rapprochement in, as for example, this quotation where the idea that the three families have been in conflict for years is expressed:

Tout en travaillant, le nez sur le sol, dans cette vigne frontière, qui est un défi à Clodius, je me demandais sourdement où j'en étais et ce que j'allais faire. Car La Jassine restait muette et les champs, par-delà les TroisBornes, ne me disaient rien de bon. Il êtait un peu plus de dix heures et pas un signe de vie ne s'y montrait.

De la terre encore humide s'élevait une bonne odeur de cep et de racine. Quelquefois je me mettais à genoux pour mieux tailler et je disparaissais au milieu des jeunes feuillages qui me touchaient les joues. J'aurais voulu n'en plus sortir, m'enraciner, faire corps avec les sarments. Mais dès que je levais la tête je voyais au pied du coteau toute l'étendue de la Théotime et, sur l'autre versant, les jachères et les maigres cultures de Clodius que j'avais peut-être tué. (Bosco 1952a 127)

Not only are the "bornes" metaphorical landmarks, but they are also in opposition to each other. For example, the bad earth of La Jassine is contrasted to Theotime's fertile soil. Pascal is tilling the land and cultivating new life while seeing in the background La Jassine; this is his challenge, or "défi," to Clodius. By working the land and making 
Théotime prosperous, Pascal defies Clodius and his ancestors. Nothing can stop him from conquering the earth which is contaminated by the neighboring La Jassine. Through a simple image of the three stones, the imagination sees the strife flaring between the Dérivat and the Clodius de Puyloubier, the correspondence to the three properties and to the image of the Trinity. In addition, the poor land and crops of La Jassine further allude to the torment festering between the two men. Pascal's challenge combats the stones, the poor land and the family conflict. This combat also relates to the physical, moral and spiritual struggle that is fought throughout the novel. All three main protagonists are involved in this struggle and, in fact, it is intertwined. That is to say that the three interrelated battles represent the evolution occurring within Pascal, Geneviève and Clodius.

But in discussing these two properties let us not forget Micolombe, the tranquil property which rests above the other two farms. This simple metaphor of a "heavenly" dwelling is opposed to the terrestrial Théotime and the decayed La Jassine. In this particular case Theotime is associated with the good earth, La Jassine with the evil, bad earth, and Micolombe with heavenly goodness. The strength of Micolombe's image as "celestial" is achieved in part by its opposition to the other two properties on one level, and on another, by its association with Geneviève. Indeed, Geneviève's ascension to spiritual awareness, the "thinking" that takes place on the part of the reader, supplements the "seeing" and leads to what is called by Ricoeur "predicative assimilation":

The assimilation consists precisely in making similar, that is, semantically proximate, the terms that the metaphorical 
utterance brings together...To see the like is to see the same in spite of, and through, the different. This tension between sameness and difference characterizes the logical structure of likeness. Imagination, accordingly, is the ability to produce new kinds by assimilation and to produce them not above the differences, as in the concept, but in spite of and through the differences. (Ricoeur 1990 427)

The evolution from the property being simply that, property, to its connection with a protagonist, demonstrates the "assimilation" of the concept of good and evil earth to that of good and evil humans. In fact, this simple dichotomy is continued to include the spiritual development of Geneviève and Pascal. The reader is invited to partake in a cognitive continuum which enables the transference of imagery from the physical limits to those which are spiritual.

In regard to that which is spiritual it is important to note Geneviève's encounter with the wild boar. In this scene she is on top of a hillside and puts herself in front of a group of boars who are moving towards Pascal:

Le troupeau s'était arrêtẻ entre Théotime et la source. A vingt pas en avant se dressait une femme; elle était mince, vêtue de noir. Elle aussi s'était arrêtée, au-delà du mas, dans les terres incultes; et elle semblait hésiter. Derrière elle on voyait les plantes de chasselas et plus loin les grandes bornes, toutes blanches de lune. A droite, le torrent.

Les bêtes ne bougeaient plus. C'êtait un troupeau de pierre; je n'en croyais pas mes yeux.

Soudain la silhouette noire remua; j'entendis une plainte et elle courut vers le torrent.

Les bêtes s'ébranlèrent. J'appelai: "Geneviève", car c'était elle, j'en êtais sûr. (Bosco 1952a 195)

This setting is indicative of several metaphoric elements. First of all, Geneviève, dressed all in black, appears to be a sorceress performing some type of incantation on the animals. Therefore, this alludes to her mystical likeness to an enchantress. The black color and the wild boar 
as symbol of evil lead the imagination to feel that this is a scene with bad connotations. However, Geneviève is not a person associated that which is bad, but rather with what is mysterious and unknown. Furthermore, the spring, a feminine symbol and associated with the unconscious, is also related to Geneviève and her ambivalent nature. These different thoughts which are evoked, create a genre of momentum which force the reader to look at all possible relationships which may exist. As Ricoeur states:

Imaging or imagining, thus, is the concrete milieu in which and through which we see similarities. To imagine, then, is not to have a mental picture of something but to display relations in a depicting mode. Whether this depiction concerns unsaid and unheard similarities or refers to qualities, structures, localizations, situations, attitudes, or feelings, each time the new intended connection is grasped as what the icon describes or depicts. (Ricoeur 1990 428-29)

Ricoeur expresses here the concept of displaying "relations in a depicting mode" which explains the process occurring in this particular event. That is to say, the image of the "bornes," the spring or "source," the uncultivated land, the herd of boars described as "troupeau de pierre," and, as already mentioned, Geneviève dressed in black, play off one another because there exists "unheard similarities"; the woman dressed in black is mystical as are the other images.

The "bornes," as was already stated, describe one of the metaphors of the limits which abound in this novel; the spring, a limit between the conscious and unconscious; the uncultivated land, indicative of the separation of La Jassine and Théotime; and Geneviève dressed in black which suggests the frontiers dividing her mystical qualities from Pascal's terrestrial ones. The various levels of limits are superimposed one on top 
of the other culminating to create an all encompassing representation of the boundaries created in this story. Moreover it produces a sense of conflict within the reader as one continuously comes up against yet another barrier and must attempt to overcome it.

As suggested by Roland Barthes there is a "jouissance," or joy, in reading a text when the reader must search for meaning:

Si je lis avec plaisir cette phrase, cette histoire ou ce mot, c'est qu'ils ont étẽ écrits dans le plaisir (ce plaisir n'est pas en contradiction avec les plaintes de l'écrivain). Mais le contraire? Ecrire dans le plaisir m'assure-t-il -- moi, écrivain -- du plaisir de mon lecteur? Nullement. Ce lecteur, il faut que je le cherche, (que je le "drague"), sans savoir où il est. Un espace de la jouissance est alors crée. Ce n'est pas la "personne" de l'autre qui m'est nécessaire, c'est l'espace: la possibilité d'une dialectique du désir, d'une imprévision de la jouissance: que les jeux ne soient pas faits, qu'il y ait un jeu. (Barthes 11)

Barthes proposes that the reader searches for the pleasure of the text without knowing where it exists and, due to this process, there is a deeper level of "jouissance" or pleasure that is almost "sensual." In the example of the wild boar scene the "jouissance" is indeed evoked through the dialectic process in search of that which is desired. Looking more closely at the description of this scene one notices that the herd is stopped between Theotime and the spring and that the woman in black is beyond the "mas" standing in the uncultivated land; behind her are the "bornes" illuminated by the moonlight. Pascal is being confronted by progressing limits; limits symbolic of the unconscious, of the division of the estates and of the family borders fortified by the three "bornes." Indeed the image created by these metaphoric elements brings to the text a greater breadth of meaning and greater "jouissance." 
Pascal's dream is another example of the creation of an image through the assimilation of the similarities. In the dream, the symbolism of the river Styx, the two river banks representing the living and the dead, the light in the chapel and Geneviève's voice are, as has already been described, images being presented one after another allowing the reader to participate in the construction of the scene:

Dans ce rêve nous voyons le lac, de la rive, sans savoir comment nous nous y retrouverons tous réunis.

C'est le bord des vivants, couvert d'ajoncs et de roseaux.

En face, où descendent des bois accrochés à de hautes falaises, on aperçoit une petite chapelle à la pointe d'un promontoire; et l'on dit qu'elle garde le rivage des morts.

Entre elle et nous, s'étendent les eaux calmes du lac...

Les eaux et les falaises s'enfoncent dans une profondeur immense entraînant avec elles les êtres imaginaires qui les ont un moment animées, et nous disparaissons nous-mêmes insensiblement pour rejoindre les lieux immobiles du sommeil...

Sur la rive opposée, où jamais de mémoire de Métidieu et de Dérivat on n'avait aperçu le moindre signe de vie, on voyait une flamme qui vacillait sous le porche de la chapelle.

Le vent tomba, les roseaux cessèrent de se plaindre, et peu à peu la vision se dissipa dans la nuit.

Seule la lampe persista longtemps à trembler dans le vide, alors que le lac et ses rives avaient déjà disparu au fond de l'abîme. (Bosco 1952a 100-2)

The dream is a realm of the unconscious which discloses Pascal's inner conflict and dilemmas by employing a semantic field which leads the reader into the abyss, an abyss that conjures up many images in the reader's mind of that which is unknown. What is unknown is the desire, for which the reader searches. The metaphoric process is not evident, but rather is a solution to an "enigma":

In other words, metaphorical meaning does not merely consist of a semantic clash but of the new predicative meaning which emerges from the collapse of the literal meaning, that is, from the collapse of the meaning which 
obtains if we rely only on the common or usual lexical values of our words. The metaphor is not the enigma but the solution of the enigma. (Ricoeur 1990 426)

The enigma created by the semantic field of: "sans savoir," "hautes falaises," "profondeurs immenses," "lieux immobiles," "vision se dispara" and "abîme" lead the reader into this unknown realm of the unconscious forcing the creation of the images of the limits which exist in this novel, that is to say, of those between the families, the estates, the conscious and unconscious and Pascal and Geneviève. Through the dislocation of these various levels of limits, a metalevel of meaning is achieved when the process of sorting amongst the visual connotations leads to the optimal view of the true meaning of the passage. Meaning is thus arrived at by categorizing the similarities, by sifting through the differences to find likeness: "It is the first task of an appropriate theory of imagination to plug this hole" (Ricoeur 1990 427). The hole, therefore, is the shift "in the logical distance from far to near" (Ricoeur 1990427 ), from two or more ideas which appear to be totally dissimilar and arriving at a meaningful crossroads. In the dream, the allusion to the river Styx and to the flame burning in the chapel evoke the idea of frontiers between Heaven and Hell, therefore, of good and evil which creates the idea of Pascal and his confusion over his feelings for Geneviève who, though not evil, is in opposition to himself by virtue of her mythical and ambivalent characteristics.

Moreover, the puzzlement which he feels is created by notions of different levels of meaning, that is, religious and spiritual thoughts forcing the reader to sort out Pascal's confusion in order to arrive at a meaningful interpretation. According to Barthes: 
La jouissance est in-dicible, inter-dite. Je renvoie à Lacan ("Ce à quoi 1 faut se tenir, c'est que la jouissance est interdite à qui parle, comme tel, ou encore qu'elle ne puisse être dite qu'entre les lignes,.,") et à Leclaire ("...celui qui dit, par son dit, s'interdit la jouissance, ou corrẻlativement, celui qui jouit fait toute lettre - et tout dit possible - s'évanouir dans l'absolu de l'annulation qu'il célèbre.") (Barthes 36-37)

What is between the lines is indeed the true meaning behind the metaphor. Pascal does not understand what he is feeling and it is precisely this ambivalence which must be conveyed through the use of metaphor. The dream, particularly because it is different from the "normal" Dérivat/Métidieu dream, is a manifestation of Pascal's schism from his other family members, that is, from all except Geneviève whose voice he believes he hears and which is a premonition of things to come. The build up to Geneviève's departure and Clodius' death are also evoked in this passage. In addition, the light which continues to flicker despite the disappearance of the lake in the depths of the abyss, is a metaphor of the hope which still exists for Pascal despite his frustration. Once again, the reader must use his feelings in order to understand, to find the key to the puzzle.

As described by Ricoeur: "The word 'insight' very often applied to the cognitive import of metaphor conveys in a very appropriate manner this move from sense to reference" (Ricoeur 1990 430). The transition from "sense" to "reference" is the "striving for truth" in the text leading, in turn, to "the sensual" pleasure that is experienced. Ricoeur adds that the referential function of language cannot be separated from the poetic function, using the expression "split reference" to suggest that poetic 
language is no less real than any other language, but that "suspension" is a complex strategy to arrive at meaning:

This suspension, however, is only the negative condition of a second-order reference, of an indirect reference built on the ruins of the direct reference...For, in another respect, it constitutes the primordial reference to the extent that it suggests, reveals, unconceals, - or whatever you say - the deep structures of reality to which we are related as mortals who are born into this world and who dwell in it for a while. (Riceour 1990 431)

The aspect of metaphor and its manipulation of thought to create images via the reader is a particularly important trait of this novel. As we have seen the process of feeling, imagining and using the cognitive process to explicate the text is critical to its reading. One cannot simply read Bosco, one must enter the story in order to reach a true comprehension. Pascal and Geneviève become real and their passions and frustrations may be better understood by developing the image in our own interpretation. We conclude with a quote from Barthes expressing this "individualization" when reading a text:

Chaque fois que j'essaye d"analyser" un texte qui m'a donné du plaisir, ce n'est pas ma "subjectivité" que je retrouve, c'est mon "individu", la donnée qui fait mon corps séparé des autres corps et lui approprie sa souffrance ou son plaisir: c'est mon corps de jouissance que je retrouve. (Barthes 98-99) 


\section{CHAPTER VII}

\section{CONCLUSION}

The previous pages have attempted to show just a small part of Henri Bosco's literary style and finesse by an examination of Le Mas Theotime. We have seen his interest in nature and in the spiritual realms which have been described and elaborated through the characters in this novel. Though this a mere glimpse of Bosco's work it is indicative of the themes found in other works such as L'Ane Culotte, Le Jardin d'Hyacinthe and Le Sanglier.

The lone man trying to find a meaning in life perhaps is closest to what Bosco was himself searching for. Pascal who was a loner, the "black sheep" of the family, was inwardly tormented and confused over his destiny in life. As in Bosco's own life, Pascal was an only child, traveling in search for the knowledge that would provide the answer to this question only to return to his family home. Though it is not known if there was a "Geneviève" in his life, it is very possible that she indeed did exist and may have been his directing force as she was for Pascal.

His travels abroad were perhaps the greatest influence on his writing. As we have seen, for example, through his interest in the Rosicrucian order, Morocco and it's rich culture provided a basis for his work in Le Mas Théotime and as Jean-Cléo Godin remarks:

Un monde donc, d'une nature extraordinaire, et qui ne ressemble en rien à la civilisation européenne. Bosco y a trouvé un grand dépaysement et des richesses humaines et 
religieuses dont il a su tirer profit. Car c'est au Maroc qu'il écrit la plus grande partie de son oeuvre. On en trouve la marque manifeste dans certaines oeuvres, et surtout dans l'Antiquaire et Le Mas Théotime. (Godin 74)

Perhaps the most significant mark of this experience in Morocco is indeed the religious aspect. The embroidered bed cover with the rose and cross, the mysterious lettering and Madeleine Dérivat's pilgrimage to Nazareth are, in part, examples of the importance of his sojourn in this distant land. In addition to these "concrete" examples of this influence, the entire religious theme in this novel is far from being conventional. Geneviève's association with the air and Pascal with the earth, further mark the depth of Bosco's examination of these characters. That is to say, their quest is not a traditional Christian one, but one that attempts to examine their rapport with God, with nature and with themselves.

In addition to the spiritual examination, the psychological aspect in this work demonstrated Bosco's interest in Jungian theory and its ramifications on an individual's behavior. This aspect also related to Bosco's interest in family lineage and the consequences of one's heritage on one's life. The Métidieu and Dérivat clan and their paradise like existence along with the violent Clodius de Puyloubier, explores the archetype theory. Pascal's special hiding place in the attic and his mysterious dreams allude to his fascination with Jung and to the portion of the human unconscious that remains out of our reach.

Bosco's use of metaphor in this novel, as in his other works, is indeed the work of a genius. Bachelard himself studied Bosco's works and his manipulation of the elements to create a meaningful and penetrating image. As Ricoeur's theory on metaphor demonstrated, the 
cognitive, imaginative and feeling qualities allow the reader to experience "jouissance" when reading the text.

When reading Bosco one enters the world of imagination and of spiritual enlightenment. The rite of initiation in Le Mas Theotime as in L'Ane Culotte is the passage to greater knowledge and contentment and is perhaps Bosco's message:

Dans L'Ane Culotte, comme dans tout récit bosquien, la Conaissance reste cependant incomplète au terme de l'initation. Si quelques secrets se dévoilent, il manque l'équivalent de l'epopteia, ou dernier degré et révélation suprême des mystère d'Eleusis. (Beckett 1990 90)

The answer in Bosco's works is never evident and it is only through continued research in "bosquien" spirituality that this may be achieved. 


\section{WORKS CONSULTED}

Bachelard, Gaston. L'Air et les Songes. Paris: Librarie José Corti, 1943.

Bachelard, Gaston. La Dialéctique de la Durée. Paris: Presses Universitaires de France, 1963.

Bachelard, Gaston. La Terre et les Rêveries du Repos. Paris: Librarie José Corti, 1963.

Bachelard, Gaston. L'Eau et les Rêves. Paris: Librarie José Corti, 1964.

Bachelard, Gaston. La Poétique de l'Espace. Paris: Presses Universitaires de France, 1964.

Bachelard, Gaston. La Poétique de la Rêverie. Paris: Presses Universitaires de France, 1965.

Barthes, Roland. Le Plaisir du Texte. Paris: Seuil, 1973.

Baudry, Robert. "Les Signes Symboliques (Dates, Noms, Figures) Dans l'Art de Henri Bosco." L'Art de Henri Bosco. Paris: José Corti, 1981. 54-84.

Beckett, Sandra. "Le Double obscur: l'appel des ombres dans Une Ombre de Henri Bosco." The French Review. 61 (1988): 552-62.

Beckett, Sandra. "Rites, magie et initiation dans L'Ane Culotte de Henri Bosco." Revue Francophone de Louisane V (1990): 83-91.

Blais, Jacques. "Mithra/Malicroix: Le Roman de Bosco et les Mythes de l'Immédiat Après-Guerre (1945-1950)." 17 (1984): 45-69.

Bosco, Henri. Irénée. Paris: Gallimard, 1928.

Bosco, Henri. Le Sanglier. Paris: Gallimard, 1932.

Bosco, Henri. L'Ane Culotte. Paris: Gallimard, 1937.

Bosco, Henri. Hyacinthe. Paris: Gallimard, 1940.

Bosco, Henri. Le Jardin d'Hyacinthe. Paris: Gallimard, 1946. 
Bosco, Henri. Malicroix. Paris: Gallimard, 1948.

Bosco, Henri. Un Rameau de la Nuit. Paris: Flammarion, 1950.

Bosco, Henri. Le Mas Théotime. Paris: Gallimard, 1952a.

Bosco, Henri. Monsieur Carré-Benoît à la Campagne. Paris: Gallimard, $1952 b$.

Bosco, Henri. Antonin. Paris: Gallimard, 1952c.

Bosco, Henri. L'Antiquaire. Paris: Gallimard, 1954.

Bosco, Henri. Les Balesta. Paris: Gallimard, 1956.

Bosco, Henri. Sabinus. Paris: Gallimard, 1957.

Bosco, Henri. L'Epervier. Paris: Gallimard, 1963.

Cavendish, Richard, ed. Man, Myth and Magic: The Illustrated

Encyclopedia of the Unknown. 11 Vols. New York: Marshall Cavendish, 1983.

Cirlot, J. E. A Dictionary of Symbols. New York: Dorsett, 1971.

de Lattre, Alain. "L'Organisation de l'Espace dans l'Univers d'Henri Bosco." L'Art de Henri Bosco. Ed. José Corti. Paris: José Corti, 1981. 205-230.

Douglas, Mary. Natural Symbols. London: Cresset P, 1970.

Eliade, Mircea. Myths, Dreams and Mysteries. New York: Harper and Brothers, 1957.

Eliade, Mircea. The Quest: History and Meaning in Religion. Chicago: U. of Chicago, 1969.

Eliade, Mircea. A History of Religious Ideas: From Stone Age to the. Eleusinian Mysteries. Vol. 1. Chicago: U of Chicago, 1978.

Fordham, Frieda. An Introduction to Jung's Psychology. New York: Penguin, 1979.

François de Sales. De la Vie Parfaite. Annecy: Gardet, 1961.

Godin, Jean-Cléo. Henri Bosco: Une Poétique du Mystère. Montréal: U de Montréal, 1968. 
Hopper, Vincent F. Medieval Number Symbolism. New York: Cooper Square, 1969.

Jakobson, Roman. Sound and Meaning. Cambridge: MIT P, 1978.

Jakobson, Roman. La Charpente Phonique du Langage. Paris: Minuit, 1979.

Jung, C. G. Psyche \& Symbol. Ed. Violet S. de Laszlo. New York: Doubleday, 1958.

Jung, C. G. The Portable Jung. Trans. R. F. C. Hull. Ed. Joseph Campbell. New York: Penguin, 1971.

Lagarde, André and Laurent Michard. Moyen Age: Les Grans Auteurs Français du Programme. Paris: Bordas, 1962.

Lévi-Strauss, Claude. La Pensée Sauvage. Paris: Plon, 1962.

Lévi-Strauss, Claude. The Elementary Structures of Kinship. Boston: Beacon, 1969.

Luccioni, Jean-Pierre. "Maîtres et Intercesseurs." Henri Bosco: Mystère et Spiritualité. Ed. José Corti. Paris: José Corti, 1987. 16590.

McKenzie, John L. Dictionary of The Bible. New York: Macmillan, 1965.

Michel, Jacqueline. Une Mise en Récit du Silence: Le Clézio-BoscoGracq. Paris: José Corti, 1986.

Rahner, Karl, ed. Encyclopedia of Theology: The Concise Sacramentum Mundi. New York: Crossroad, 1982.

Ricoeur, Paul. "The Metaphorical Process as Cognition, Imagination, and Feeling." Critical Theory Since 1965. Ed. Hazard Adams and Leroy Searle. Tallahassee: Florida State UP, 1986. 423-34.

Ricoeur, Paul. The Rule of Metaphor. Buffalo: U of Toronto P, 1979.

Rosso, Corrado. "Le mas Théotime de Henri Bosco et la Tentation du Bergsonisme." Henri Bosco: Mystère et Spiritualité. Ed. José Corti. Paris: José Corti, 1987. 149-63.

Roy, Jean-Pierre. Bachelard ou Le Concept Contre l'Image. Montréal: U de Montréal, 1977. 
Smith, Arlette M. "Les Gens de la terre dans l'oeuvre romanesque d'Henri Bosco." The French Review. LXI (1985): 65-73.

Vries, Ad de. Dictionary of Symbols and Imagery. Amsterdam: North Holland, 1984.

Waite, Arthur E. The Brotherhood of the Rosy Cross. New York: University Books, 1961. 